Article

\title{
Comparative Analysis of the Effects of Daily Eating Habits and Physical Activity on Anthropometric Parameters in Elementary School Children in Latvia: Pach Study
}

\author{
Ilze Justamente ${ }^{1,2}$, Jelena Raudeniece ${ }^{1,2}{ }^{\mathbb{D}}$, Liga Ozolina-Moll ${ }^{1}$, Amelia Guadalupe-Grau ${ }^{3}$ \\ and Dace Reihmane $1,2, *$ D \\ 1 Department of Human and Animal Physiology, Faculty of Biology, University of Latvia, Jelgavas Street 1, \\ LV-1004 Riga, Latvia; ilze.justamente@lu.lv (I.J.); jelena.raudeniece@lu.lv (J.R.); \\ liga.ozolina-molla@lu.lv (L.O.-M.) \\ 2 Department of Human Physiology and Biochemistry, Riga Stradiňš University, Dzirciema Street 16, \\ LV-1007 Riga, Latvia \\ 3 ImFINE Research Group, Department of Health and Human Performance, Universidad Politécnica de \\ Madrid, 28040 Madrid, Spain; amelia.guadalupe@upm.es \\ * Correspondence: dace.reihmane@lu.lv; Tel.: +371-26032249
}

Received: 30 October 2020; Accepted: 10 December 2020; Published: 14 December 2020

\begin{abstract}
Growing incidence of obesity and related diseases in children poses new challenges and calls for a review of lifestyle habits. This study aimed to assess daily eating habits (EH) and physical activity (PA) levels and identify their association with obesity in 8-10-year-old children. Children's EH and time spent in moderate-to-vigorous physical intensity (MVPA) was estimated from questionnaires $(N=1788)$. Weight, height, and waist circumference (WC) were collected, and body mass index (BMI) calculated. Girls consumed more fruits and vegetables, drank more water, and ate smaller portions of carbohydrate and protein rich foods but spent less time in MVPA compared to boys $(p<0.05)$. Obese children skipped breakfast more often and consumed less fruits and vegetables. Children who chose to eat in front of the screen had higher WC $(62.88 \pm 8.70$ vs $60.59 \pm 7.40 \mathrm{~cm}, p<0.001)$ and higher BMI, and chose smaller vegetable portions and more calorie dense snacks $(p<0.001)$. $15.4 \%$ of pupils covered weekly MVPA recommendations with structured PA on weekdays. Increasing MVPA was related to a smaller number of unhealthy EH $(p<0.001)$. In conclusion, EH and PA levels differ between sexes and obese children have unhealthier EH. Higher levels of MVPA are related to healthier food choices, while pupils having meals in front of the screen have unhealthier EH and anthropometric measures. The majority of pupils did not reach the WHO recommendations of MVPA through structured PA on weekdays. Association between factors (EH and time spent in PA) and BMI was not found in this study.
\end{abstract}

Keywords: structured physical activity; eating habits; body mass index; pupils; elementary school

\section{Introduction}

Overweight and obesity rates among children are rising in parallel with increased consumption of high energy dense foods, drinks, and inactive lifestyle causing health issues such as diabetes, cardiovascular and musculoskeletal diseases, and even cancer [1]. In addition, childhood obesity is more likely to be persistent into adulthood [2,3], also causing a variety of psychosocial complications [4]. Thus, the epidemic of obesity is raising concerns not only on the individual level, but also on the social level. Early interventions and lifestyle changes during childhood are the most important measures to 
prevent obesity-associated diseases in adults [5], where family lifestyle habits play a crucial role in the formation of the child's behavior.

The World Obesity Federation predicts that by the year 2030, the number of obese children aged 5-19 will grow from 158 million in 2020 and reach 254 million [6]. In 2006, the World Health Organization initiated the European Child Obesity Surveillance Initiative (COSI) to monitor obesity in childhood and to use the data to introduce changes in overweight and obesity prevention programs. In 2018, results for Latvian pupils aged 9 showed that $27.2 \%$ boys and $22.9 \%$ girls were overweight or obese. $58.3 \%$ of these children participated in moderate-to-vigorous physical activity (MVPA) for at least $4 \mathrm{~h}$ weekly, but during the weekends $56.9 \%$ used an iPad, smart phone, computer and watched TV for $3 \mathrm{~h}$ or more [7]. Importantly, overweight and obesity have increased in comparison with 2008.

Healthy eating patterns and PA are associated with healthy BMI among children. Unhealthy dietary patterns such as breakfast skipping, overeating, and rare participation in family meals are associated with total and central body adiposity, increased BMI and waist-to-height ratio $[8,9]$. To maintain healthy weight and avoid unhealthy weight gain, it is important to balance energy intake through healthy foods and beverages and energy expenditure with basal metabolic rate (BMR) and PA. Previous studies reported that children with higher BMI had unhealthier EH and more sedentary lifestyle habits [10]. For example, it has been shown that obese and overweight pupils more often skipped breakfast [11], consumed more ultra-processed calorie dense foods [12] and had lower MVPA levels $[13,14]$.

According to EuroStat data, the obesity rate in adults in Latvia (in the population aged 18 years and over) is one of the highest in the European Union (following Malta, which is ranked first in obesity prevalence) [15], so it is particularly important to pay attention to children's health indicators to reduce the risk of obesity and obesity-related diseases in the future. Improvements in diet and increase in PA have been shown to be cost-effective in terms of reducing medical costs, thus being an important part of various obesity prevention strategies [16,17].

There are some studies examining EH and PA in various age groups and sexes [7,18]; however, differences in behavioral patterns among weight groups have not been described in Latvian children. Therefore, this study aimed to analyze EH, PA, and anthropometric parameters among 8-10-year-old children in different weight groups and by sex, and to determine the relations and impact of measured parameters on BMI and WC.

\section{Materials and Methods}

\subsection{Study Design and Subjects}

This paper describes the baseline characteristics of pupils enrolled in the Physical Activity and Children Overall Health (PACH) study and presents data related to this cross-sectional quantitative research design. The study involved $17888-10$-year-old pupils from the second $(n=1119)$ and third class $(n=669)$ of which $53.5 \%(n=957)$ were boys and $46.5 \%(n=831)$ were girls who joined the Latvian Olympic Committee project "Sport for All Classes" (SFAC) in the school year 2019/2020. Project SFAC is supported by the Ministry of Education and Science of Latvia and ensures 5 vs 2 school-based PE lessons per week, promoting structured physical activities in schools. To participate in SFAC, school authorities (principals, form teachers, and physical education teachers) had to submit an official application with the list of pupils and corresponding signatures of their parents.

The PACH study is an effective collaboration project between the University of Latvia and the Latvian Olympic Committee (ZD2019/20861) and has been developed in line with the Declaration of Helsinki (World Medical Association) and corresponds to ethical principles for medical research involving human subjects. 59 different schools representing all five statistical regions of Latvia, Vidzeme (13), Latgale (1), Zemgale (7), Kurzeme (11), Riga (27), were enrolled in the study through convenience sampling. The PACH study has been approved by the Ethical Committee of the Institute of Cardiology and Regenerative Medicine, University of Latvia (Nr.179/2019; effective from 14.10.2019). 
Parents were asked to sign a detailed written consent explaining all procedures and possible risks, and data collection and management procedures for participation in the $\mathrm{PACH}$ study providing that their child was taking part in the SFAC project. Verbal consent from subjects was obtained and they had the right at any point without explanation to refuse further participation in the study.

\subsection{Measures}

\subsubsection{Anthropometric Measurements}

To estimate obesity prevalence among 8-10-year-old pupils, data on weight, height, and WC were collected. Based on these measurements, BMI for each child (body weight $(\mathrm{kg}) /$ body height squared (m2)) and percentile was calculated [19]. After calculation of BMI, four study groups were distinguished: underweight (UW, $<5$ th percentile); normal (NOR, 5th-85th percentile); overweight (OW, 85th-95th percentile); obese (OB, above 95th percentile). Anthropometric measurements were also compared between sexes.

\subsubsection{Eating Habits}

To evaluate pupils' EH among study groups and by sex, a questionnaire based on the content of the healthy eating guidelines of the Ministry of Health of the Republic of Latvia and a project of the United States Department of Agriculture "My Plate" was designed. It included an estimation of $7 \mathrm{EH}$ commonly described in the scientific literature: eating breakfast [20], number of daily meals [21], fruit and vegetable consumption [22], choice of snacks [23] and beverages [4,24] and eating culture, e.g., watching TV while eating $[25,26]$. Current evidence suggests that eating while viewing the screen leads to obesity in children [27], thus an additional analysis estimating differences in BMI, WC, and other measured parameters were analyzed in pupils eating at the table and pupils eating in front of the screen. More detailed description of the survey items, answers, and correspondingly adapted scoring system (0-6 points) for the total number of unhealthy EH $[11,20,21,24,28-36]$ is presented in Table A1.

\subsubsection{Meal Portion Size}

Daily energy intake is considered one of the main factors causing obesity causing. Larger meal portions result in higher daily energy intake. To determine the dietary intake among different study groups and sexes, meal portion size for carbohydrate foods, protein rich foods and vegetables/salads were estimated. Pictures representing the size of portions were chosen from the Photographic Atlas of Food Portions for the Emirate of Abu Dhabi, 2014 [37]. More detailed description of the estimation of portion sizes in grams [32] is presented in Table A1.

\subsubsection{Time Spent in Structured Physical Activity}

It has been shown that health-related physical fitness is primarily associated with PA during PE lessons and in recess, and engaging in sports/dance, but not with participation in nonorganized physical play outside school [38], thus the current study focused on structured PA on weekdays. Questions about such daily habits as means of getting to school, number of PE lessons in school, and participation in professional training (team and individual sports) and activities during breaks between school lessons were asked. Pupils' answers were used to calculate time spent in light $(<3$ youth metabolic equivalents (METy), moderate (3-6 METy) and vigorous ( $>6$ METy) PA as well as to estimate the prevalence of pupils reaching the WHO recommendations of MVPA per weekdays and for whole week. More detailed description of the survey items, answers, and correspondingly adapted METy from the Youth Compendium [39] is presented in Table A2.

\subsubsection{Total Energy Cost during Structured Physical Activity}

Total energy costs were estimated based on METy from the Youth Compendium [39], a computed $\mathrm{BMR}$, and duration of the specific activity, as follows: Total energy cost $(\mathrm{kcal})=\mathrm{METy} \times \mathrm{BMR}(\mathrm{kcal} / \mathrm{min})$ 
$\times$ duration ( $\mathrm{min}$ ), where BMR for 3-10-year-old girls and boys is predicted from Schofield equation $(\mathrm{BMR}(\mathrm{kcal} / \mathrm{min})=(20.315 \times$ Weight $(\mathrm{kg})+485.9) / 1440$ and BMR $(\mathrm{kcal} / \mathrm{min})=[22.706 \times$ Weight $(\mathrm{kg})+504.3] / 1440$, correspondingly). Study groups were described in relation to time spent in PA (reaching or not reaching WHO recommendations). In these calculations, $N$ was comparatively lower, because children lacking data for BMI calculation and with incomplete/incorrect questionnaires about PA were excluded from the analysis. More detailed description of the estimation of total energy cost during structured PA is presented in Table A2.

\subsection{Procedure}

Examination of the subjects occurred in the school setting. Research team visited pupils once between November 2019 and January 2020. Questionnaires estimating EH, meal portion size, and PA levels were electronic, and pupils filled them out on school computers with the assistance of their teacher and/or researcher. Additionally, questions were represented with pictures to keep children's attention and facilitate the answering process.

Medical nurses working in the schools were trained by the study research group and assisted in the collection of anthropometric measurements performed according to a standardized protocol (COSI) [40] and local school equipment was used. Body height was measured using a stadiometer, standing straight as possible and arms hanging freely along the sides. Height was measured in centimeters and the reading was taken until the last completed $1 \mathrm{~mm}(0.1 \mathrm{~cm})$. The body weight of the children was measured in kilograms and recorded to the nearest $100 \mathrm{~g}(0.1 \mathrm{~kg})$ unit. Children were weighed without shoes in light sportswear. Waist was measured to the nearest $0.5 \mathrm{~cm}$ with an anthropometric nonelastic measuring tape after normal expiration, at the level of the umbilicus. Sample size across variables varies due to data collection on different days (in some of the schools), sickness, or refusal to participate in particular measurements. Out of 1788 pupils recruited in the study, BMI was determined for 1645 children.

\subsection{Statistical Analysis}

Shapiro-Wilks test was used to check the data for normality. Any differences between study groups are explained using the nonparametric (Mann-Witney U test) test. Quantitative data defined by more than two categories were tested using the Kruskal-Wallis test. The Chi Square test was used to analyze differences between study groups reported as categorical data. To see which categories have the largest difference between the expected counts, adjusted residuals $(-2,2)$ were used. Spearman's correlation test was used to determine relations between variables. Characterizing the strength of the interaction between the traits, the correlation was evaluated as close (if $r \geq 0.7)$, medium $(0.3<r<0.7)$, or weak (if $r \leq 0.3$ ). Multiple linear regression (MLR) was used to model the linear relationship between the independent variables (number of daily meals and additional snacks, fruit and vegetable consumption (number of portions per day), meal portion sizes described in point 2.2.3., total time spent in PA and subgroups (light, moderate, vigorous) and dependent variables (BMI and WC)). Data were processed with SPSS 21 (Statistical Package for the Social Sciences, IBM, Armonk, NY, USA), expressed as median and quartile I ( $25 \%)$ and III $(75 \%)$ and as mean rank.

\section{Results}

\subsection{Anthropometric Measurements}

BMI prevalence among the pupils were $4.9 \%$ UW; $72.3 \%$ NOR; $9.4 \%$ OW and $13.3 \%$ OB. It was determined that $9 \%$ of boys were OW and $15,5 \%$ were OB, while $9.9 \%$ of girls were OW and $10.7 \%$ were OB. Obesity prevalence was found to be significantly higher in boys compared to girls $(\chi 2(3)=8.37, p=0.039)$. Table 1 represents the median anthropometric data of the study groups and by sex. 
Table 1. General anthropometric characteristics of the study groups and by sex.

\begin{tabular}{ccccccc}
\hline & UW $(\boldsymbol{N}=\mathbf{8 1})$ & NOR $(\boldsymbol{N}=\mathbf{1 1 9 0})$ & OW $(\boldsymbol{N}=\mathbf{1 5 5})$ & OB $(\boldsymbol{N}=\mathbf{2 1 9})$ & Boys $(\boldsymbol{N}=\mathbf{8 9 0})$ & Girls $(\boldsymbol{N}=\mathbf{7 5 9 )}$ \\
\hline Weight, $\mathrm{kg}$ & $24(22 ; 26)$ & $29(26 ; 32)$ & $36(33 ; 39)$ & $43(39 ; 50)$ & $31(28 ; 35)$ & $30(26 ; 34)^{*}$ \\
Waist, $\mathrm{cm}$ & $55(53 ; 58)$ & $59(56 ; 61)$ & $66(62 ; 70)$ & $76(70 ; 81)$ & $60(57 ; 65)$ & $59(55 ; 64)^{*}$ \\
BMI, $\mathrm{kg} / \mathrm{m}^{2}$ & $13.5(13 ; 14)$ & $16(15 ; 17)$ & $19(19 ; 20)$ & $22(21 ; 24)$ & $17(15 ; 18)$ & $16(15 ; 18)^{*}$ \\
\hline
\end{tabular}

UW-underweight; NOR—normal weight; OW—overweight; OB-obese. * Significant difference compared to boys $(p<0.001)$.

\subsection{Eating Habits}

Table 2 summarizes the study data on six EHs assessed in 8-10-year-old pupils. Dietary surveys indicated that most of the pupils (59.2\%) had their breakfast every day, $16.2 \%$ almost every day, $22.9 \%$ sometimes, while only $1.9 \%$ children admitted that they did not eat breakfast at all. Statistical analysis showed that obese children skipped breakfast more often than children in NOR or UW groups $(\chi 2(9)=8.76, p=0.033$, Table 2), while the difference between sexes was not observed.

Table 2. Eating habits among the study groups and by sex.

\begin{tabular}{|c|c|c|c|c|c|c|}
\hline & UW & NOR & OW & OB & Boys & Girls \\
\hline \multicolumn{7}{|c|}{ Eating breakfast every day (\% of pupils) } \\
\hline$\%(\mathrm{~N})$ & $66.7(52)$ & $60.0(677)$ & $57.6(83)$ & $50(102) *$ & $59.8(536)$ & $58.6(465)$ \\
\hline \multicolumn{7}{|c|}{ Fruit and vegetable consumption (number of portions per day) } \\
\hline Median & $4(3 ; 5)$ & $4(3 ; 5)$ & $4(3 ; 6) *$ & $4(3 ; 5)$ & $4(3 ; 5)$ & $4(3 ; 5)$ \\
\hline $\begin{array}{l}\text { (Q1;Q3) } \\
\mathrm{N}\end{array}$ & 78 & 1128 & 144 & 203 & 896 & 794 \\
\hline \multicolumn{7}{|c|}{ Fruit and vegetable consumption ( $\%$ of pupils eating recommended $\geq 5$ portions per day) } \\
\hline$\%(\mathrm{~N})$ & $43.6(34)$ & $46.4(523)$ & $49.3(71)$ & $38.2(78)$ & $43.2(387)$ & $49.0(389) * *$ \\
\hline \multicolumn{7}{|c|}{ Vegetable consumption ( $\%$ of pupils eating recommended $\geq 3$ portions per day) } \\
\hline$\%(\mathrm{~N})$ & $30.8(24)$ & $37.1(418)$ & $41.7(60)$ & $28.4(58) *$ & $34.4(308)$ & $38.2(303)$ \\
\hline \multicolumn{7}{|c|}{ Fruit consumption ( $\%$ of pupils eating recommended $\geq 2$ portions per day) } \\
\hline$\%(\mathrm{~N})$ & $65.4(51)$ & $73.0(824)$ & $78.5(113)$ & $66.7(136) *$ & $71.9(644)$ & $73.7(585)$ \\
\hline \multicolumn{7}{|c|}{ Choice of beverage (\% of pupils choosing water) } \\
\hline$\%$ & $39.7(31)$ & $41.0(463)$ & $36.1(52)$ & $45.6(93)$ & $35.5(318)$ & $48.1(382)^{* *}$ \\
\hline \multicolumn{7}{|c|}{ Eating culture (\% of pupils eating in front of TV or while scrolling the telephone) } \\
\hline$\%$ & $26.9(21)$ & $27.5(310)$ & $34.0(49)$ & $35.3(72)$ & $32.8(294)$ & $24.3(193)^{* *}$ \\
\hline \multicolumn{7}{|c|}{ Number of total unhealthy eating habits } \\
\hline Median & $2(1 ; 3)$ & $2(1 ; 3)$ & $2(0 ; 3)$ & $2(1 ; 3)$ & $2(1 ; 3)$ & $1(0 ; 3) * *$ \\
\hline $\begin{array}{l}\text { (Q1;Q3) } \\
\mathrm{N}\end{array}$ & 28 & 505 & 59 & 109 & 409 & 345 \\
\hline
\end{tabular}

Number of daily meals was estimated as one of the EH. The majority of pupils $(47.7 \%)$ reported having the recommended three meals per day followed by four and five meals $(24.6 \%)$, two or fewer meals $(24.3 \%)$, and six or more meals (3.6\%) per day. Average number of daily meals was similar in all weight groups and did not differ between sexes (data not shown).

Study data showed that $46.1 \%$ of pupils ate five-eight recommended fruit and vegetable portions per day. Girls reached the recommendations more often $(\chi 2(1)=5.70, p=0.19$, Table 2) while a significant difference between study groups was not found (Table 2). However, study data showed that $\mathrm{OB}$ pupils on average ate less fruit and vegetable portions per day in comparison to OW weight group $(\mathrm{H}(3)=8.75, p=0.033$, Table 2$)$. When viewed separately, girls chose to eat more portions of vegetables than boys (mean rank for girls 874 vs mean rank for boys $820, U=332802.50, z=-2.37$, $p=0.018$ ). However, children in the OB group ate fewer portions of vegetables compared to NOR and OW groups (701 vs 787 vs 820 mean rank, respectively, $\mathrm{H}(3)=8.53, p=0.036$ ), correspondingly, 
less often reaching the recommended three or more portions of vegetables per day $(\chi 2(3)=8.55$, $p=0.036$, Table 2). Similarly, $72,8 \%$ of pupils ate the recommended two or more portions of fruits per day, and OB pupils reached the norm less often $(\chi 2(3)=8.16, p=0.043$, Table 2$)$. Study data showed that pupils independent of study group or sex preferred fruits more than vegetables $(N=415$ choose more vegetables, $N=524$ choose more fruits, Wilcoxon Signed Rank Test, $\mathrm{T}=250529, \mathrm{z}=-3.84$, $p<0.001)$ in their daily menu.

Fruits $(55.7 \%)$ were also the most often mentioned snack among all study participants, followed by nuts and dried fruits $(11.7 \%)$, salty snacks (e.g., chips, fries) $(10.7 \%)$, cookies and biscuits $(8.6 \%)$, yogurt (8.5\%) and chocolate, candies and ice cream (4.9\%). Similarly, data showed that fruits (49.7\%) were the most popular snack choice between meals for pupils $(n=754)$ that marked only one favorite snack. Snack choices in different weight groups were similar, but pupils in OW group tended to eat more dried fruits and nuts, while pupils in UW group tended to eat more biscuits, muffins, and cakes $(\chi 2(15)=25.07 p=0.049$, Figure 1). As can be seen in Table 2, a significant difference between the use of calorie dense snacks among study groups or sexes was not observed, however, boys tended to eat more calorie dense snacks than girls $(\chi 2(1)=2.91, p=0.093)$. Data analysis also revealed that boys chose to eat salty calorie dense snacks more often, while girls chose such sweets as cookies and muffins $(\chi 2(5)=34.34, p<0.001)$. In all study groups, the number of daily snacks taken was similar. Most of the children (48.7\%) chose to eat two-three additional snacks per day, followed by $22.0 \%$ eating one, $17.7 \%$ eating four and five, while $8.5 \%$ of children ate six and more additional snacks per day. Differences between study groups and sex were not observed.

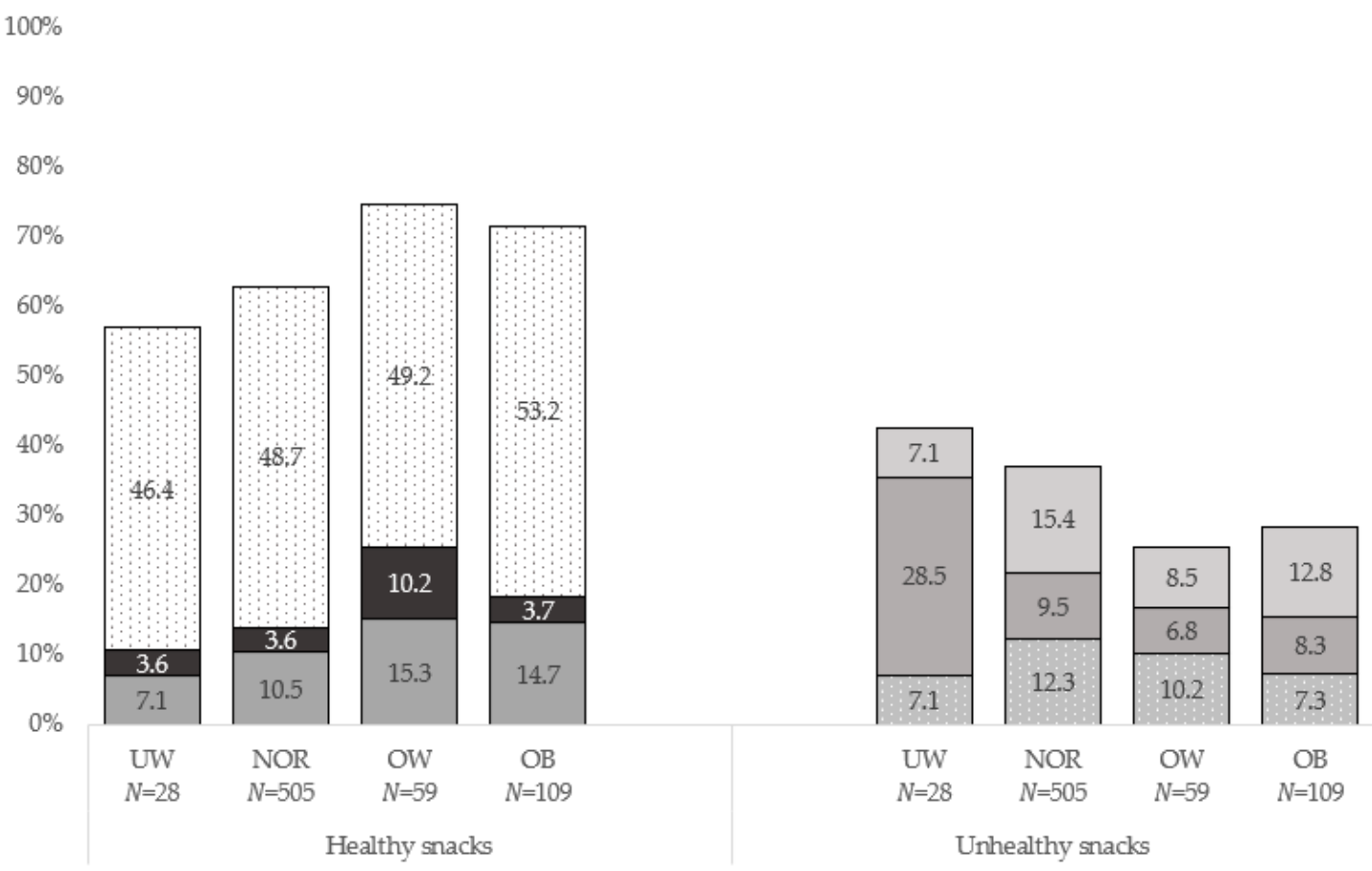

$\square$ Yogurt, drinking yogurt

$\square$ Chocolate, chocolate bars, candies, ice cream

$\square$ Nuts, dried fruits

$\square$ Biscuits, muffins, cakes

$\square$ Fresh fruit

$\square$ Chips, salted nuts, french fries, popcom (savory snacks)

Figure 1. Proportion of snack intake in various weight groups. UW—underweight; NOR—normal weight; OW-overweight; OB-obese.

Less than half of the children (41.0\%) chose water to quench their thirst, followed by tea (25\%), fruit juices (17.3\%), and sweetened drinks (16.3\%) such as Coca Cola, Fanta, and Sprite. Girls drank 
water more often than boys, while boys drank more sweetened beverages $(\chi 2(3)=41.77, p<0.001$, Table 2). Significant differences between study groups were not observed (Table 2).

Most of the children indicated that they usually had a meal at the table alone or with the family (71.1\%). However, as shown in Table 2, boys watched TV, looked at the computer, or used mobile devices during the meal more often than girls $(\chi 2(1)=14.85, p<0.001)$. Similarly, OB and OW pupils tended to eat more in front of the screen in comparison to other study groups $(\chi 2(3)=7.10, p=0.069$, Table 2). Those children who chose to eat in front of the TV, computer or scrolling a phone had a higher BMI $(\mathrm{U}=228563.50, \mathrm{z}=-2.55, p=0.011)$, and waist circumference $(\mathrm{U}=205913.00, \mathrm{z}=-4.02, p<0.001)$ and unhealthier eating habits (Table 3$)$.

Table 3. Anthropometric parameters and eating habits in pupils eating at the table or in front of the screen.

\begin{tabular}{|c|c|c|c|c|c|}
\hline & BMI, $\mathrm{kg} / \mathrm{m}^{2}$ & Waist, cm & $\begin{array}{l}\text { Vegetables, } \\
\text { Portions per Day }\end{array}$ & $\begin{array}{l}\text { Calorie Dense } \\
\text { Snack, Ranks }\end{array}$ & $\begin{array}{c}\text { Number of } \\
\text { Unhealthy Eating } \\
\text { Habits (EH) }\end{array}$ \\
\hline \multicolumn{6}{|c|}{ Pupils Eating at the Table } \\
\hline Median (Q1; Q3) & $16(15 ; 18)$ & $60(56 ; 64)$ & $2(2 ; 3)$ & $1(1 ; 3)$ & $1(0 ; 2)$ \\
\hline $\mathrm{N}$ & 1102 & 1070 & 1203 & 546 & 546 \\
\hline \multicolumn{6}{|c|}{ Pupils Eating in Front of the Screen } \\
\hline Median (Q1; Q3) & $17(15 ; 19)$ * & $61(57 ; 66)^{* *}$ & $2(1 ; 3) * *$ & $3(1 ; 4) * *$ & $3(2 ; 4) * *$ \\
\hline $\mathrm{N}$ & 452 & 443 & 487 & 208 & 208 \\
\hline
\end{tabular}

* Significant difference between groups $(p<0.05),{ }^{* *}$ Significant difference between groups $(p<0.001)$

In a sample size of 754 pupils, most of the children had two or less unhealthy EH, while $32.5 \%$ of the children reported three or more unhealthy EH like skipping breakfast, eating while watching TV, not eating enough vegetables, etc. Unhealthy $\mathrm{EH}$ were more common among boys compared to girls $(1.94 \pm 1.39$ vs. $1.66 \pm 1.45, p=0.003$, Table 2$)$.

\subsection{Meal Portion Size}

Boys in comparison to girls chose to put on the plate a bigger portion of carbohydrate containing foods such as potatoes, pasta, rice $(\mathrm{U}=304295.00, \mathrm{z}=-5.25, p<0.001)$, as well as protein-rich foods such as meat and fish $(\mathrm{U}=299890.00, \mathrm{z}=-5.67, p<0.001)$ (Table 4) while portion sizes were similar in all weight groups (data not shown).

Table 4. Meal portion size by sex.

\begin{tabular}{ccc}
\hline & Boys & Girls \\
& $(N=896)$ & $(N=794)$ \\
\hline Carbohydrate Rich Food, Grams per Portion & $253(175 ; 331)$ & $253(175 ; 331) *$ \\
Mean Ranks & 903 & 781 \\
\hline Vegetable/Salad, Grams per Portion & $85(56 ; 145)$ & $85(56 ; 145)$ \\
Mean Ranks & 843 & 848 \\
\hline Protein Rich Food, Grams per Portion & $168(108 ; 191)$ & $108(56 ; 168) *$ \\
Mean Ranks & 908 & 775 \\
\hline
\end{tabular}

* Significant difference compared to boys $(p<0.05)$.

\subsection{Time Spent in Structured Physical Activity}

The majority of the pupils reported that they use every opportunity to move actively, because they like to do so $(44,6 \%)$, while less than $5 \%$ of children reported that they do not like to move actively at all, preferring to sit still or walk calmly. Children in the OB group reported that they prefer to be less active compared to UW, NOR, and OW groups $(\chi 2(12)=37.16, p<0.001)$. 
More than half of the children (52.4\%) got to school by car, 33.7\% walked to school, and $13.9 \%$ used public transport. Data showed that most children lived relatively close to school and it took less than $10 \mathrm{~min}$ to get to school, both on foot and by car. Almost $70 \%$ of the study participants had an additional PA besides the PE at school. Furthermore, $80.4 \%$ of them did sports training 2-4 times a week. Data showed that boys were more likely to report additional PA outside the school curriculum and they had more training sessions per week compared to girls $(3(2 ; 4)$ vs $2(2 ; 3))$. More than half of the pupils (57.1\%) preferred to be active in school breaks (running, playing active games), and again boys reported being more active compared to girls $(\chi 2(4)=63.02, p<0.001)$. When asked what pupils prefer to do in their free time, one-third of children (33.8\%) answered that they usually watch TV, play computer games, or use the telephone. Only a quarter $(26 \%)$ of children chose to play with friends, sisters, or brothers. Less popular free time activities were reading, helping parents with household work, or going for a walk with a dog $(14.4 \%, 12 \%$, and $11.8 \%$ respectively).

On average, in structured PA on schooldays ( 5 days a week), $49.8 \%$ of the pupils reached the WHO recommendation of $60 \mathrm{~min}$ of MVPA per day (300 min per 5 days), while only $15.4 \%$ reached this throughout the whole week (420 min in total, respectively). Study data showed that boys more often reached the WHO recommendations than girls, primarily due to increased time spent in MVPA $(\chi 2(1)=50.07, p<0.001$, Table 5). Only $22 \%$ boys and $17 \%$ girls reported participation in vigorous PA. Total time spent in structured PA on weekdays was $550(375 ; 650) \mathrm{min}$, while in structured MVPA this was $295(175 ; 390)$ min but was significantly higher in boys when compared to girls $(U=319095$, $\mathrm{z}=-3.690, p<0.001$ and $\mathrm{U}=286151.00, \mathrm{z}=-6.98, p<0.001$, respectively). Differences between the weight groups were not observed (data not shown).

Table 5. Physical activity levels by sex.

\begin{tabular}{ccc}
\hline & $\begin{array}{c}\text { Boys } \\
(\mathbf{N}=\mathbf{8 9 6})\end{array}$ & $\begin{array}{c}\text { Girls } \\
(\mathbf{N}=\mathbf{7 9 4})\end{array}$ \\
\hline Total PA, min & $550(375 ; 650)$ & $550(350 ; 625) *$ \\
\hline Light PA, min & $200(110 ; 295)$ & $265(200 ; 295) *$ \\
\hline Moderate, min & $295(190 ; 390)$ & $255(175 ; 350) *$ \\
\hline $\begin{array}{c}\text { Moderate-to-vigorous physical activity } \\
\text { (MVPA), min }\end{array}$ & $330(210 ; 390)$ & $270(175 ; 370) *$ \\
\hline $\begin{array}{c}\text { Prevalence (\%) of pupils reaching the } \\
\text { recommended daily amount of MVPA } \\
\text { during school time and trainings per 5 days }\end{array}$ & 57.9 & \\
\hline * Significant difference compared to boys $(p<0.05) .{ }^{* *}$ Significant difference compared to boys $(p<0.001)$.
\end{tabular}

\subsection{Total Energy Cost During Structured Physical Activity}

The total energy costs to sustain previously described PA levels are listed in Table 6 according to whether pupils had or had not met the WHO recommended 60 min of MVPA during every weekday. There was a significant difference $(p<0.01)$ in the total energy costs between most of the groups except the ones noted in Table 6. 
Table 6. Total energy costs of the study groups and by sex.

\begin{tabular}{|c|c|c|c|c|c|}
\hline UW & NOR & OW & OB & Boys & Girls \\
\hline \multicolumn{6}{|c|}{ Total Energy Cost (kcal/week) of Pupils Used for Structured Physical Activities Lasting $\geq 300$ min/week } \\
\hline 2011 & 2314 & 2643 & 2991 & 2580 & 2113 \\
\hline$(1704 ; 2284) * \#$ & $(2039 ; 2663)$ & $(2335 ; 3058)$ & $(2613 ; 3441)$ & $(2282 ; 2971)$ & $(1865 ; 2377)$ \\
\hline$N=30$ & $N=502$ & $N=59$ & $N=77$ & $N=410$ & $N=259$ \\
\hline \multicolumn{6}{|c|}{ Total Energy Cost (kcal/week) of Pupils Used for Structured Physical Activities Lasting < $300 \mathrm{~min} /$ week } \\
\hline 1527 & 2314 & 1792 & 2070 & 1807 & 1567 \\
\hline$(1268 ; 1709) *$ & $(1419 ; 1804) *$ & $(1667 ; 1922)$ & $(1852 ; 2329)$ & $(1571 ; 2005)$ & $(1390 ; 1759)$ \\
\hline$N=18$ & $N=269$ & $N=44$ & $N=55$ & $N=175$ & $N=211$ \\
\hline
\end{tabular}

\subsection{Correlations Between Measured Parameters}

Several correlations between parameters characterizing EH and PA and anthropometric measurements were found in the whole study population (Table 7). Correlation analysis of separate groups showed that time spent in PA in OB pupils were related to lower BMI $(r=-0.141 . p=0.044)$ and lower WC $(r=-0.182 . p=0.010)$. In addition, OB pupils who skipped breakfast more often had higher waist circumference $(r=-0.163 ; p=0.041)$.

Table 7. Correlation coefficients characterizing relations between independent (measures) and dependent (anthropometric measurements) variables.

\begin{tabular}{ccc}
\hline & BMI, kg/m $\mathbf{m}^{\mathbf{2}}$ & Waist, $\mathbf{c m}$ \\
\hline Number of Daily Meals, Meals per Day & $r=0.019$ & $r=-0.003$ \\
\hline Breakfasts Frequency & $r=-0.082{ }^{* * *}$ & $r=-0.100 * * *$ \\
\hline Carbohydrate Portion, gr & $r=0.030$ & $r=0.043$ \\
\hline Meat/Fish Portion, gr & $r=0.021$ & $r=0.045$ \\
\hline Vegetable Portion, gr & $r=-0.017$ & $r=0.007$ \\
\hline Vegetables and Fruit, Portions per Day & $r=-0.035$ & $r=-0.044^{*}$ \\
\hline Calorie Dense Snacks & $r=-0.063 *$ & $r=-0.059 *$ \\
\hline Enjoying Physical Activities & $r=-0.051{ }^{* *}$ & $r=-0.079 * *$ \\
\hline Time Spent in MVPA, min & $r=0.012$ & $r=-0.004$ \\
\hline Additional Trainings, Number per Week & $r=-0.006$ & $r=-0.055^{*}$ \\
\hline$*$ Tendency $(p<0.1) .{ }^{* *}$ Significant difference $(p<0.05) .{ }^{* * *}$ Significant difference $(p<0.001)$.
\end{tabular}

Higher total energy costs were also related to bigger portions of carbohydrate-containing foods $(r=0.130, p<0.001)$ and bigger portions of meat or fish $(r=0.166, p<0.001)$. In addition, the relation between increasing structured PA (total time spent in light to vigorous PA) and lower number of unhealthy EH was found, $r=-0.112, p=0.002$ )

\subsection{Multiple Linear Regression}

A multiple linear regression model was used to assess whether time spent in structured PA and $\mathrm{EH}$ affected anthropometric measurements (BMI and WC) but gained no significant results. The results of the regression indicated that ten predictors explained only $1.1 \%$ of the variance and that the model was a significant predictor of WC $(\mathrm{R} 2=0.011, \mathrm{~F}(9,1503)=1.93 p=0.045)$. It was found that the number of vegetable and fruit portions per day was a significant predictor for WC $(\beta=-0.288, p=0.014)$ and total time spent in light physical activity $(\beta=-0.005, p=0.042)$, whereas other factors did not 
show significant results. The results of the regression indicated that ten predictors explained only $0.5 \%$ of the variance and that the model was not a significant predictor of BMI $(\mathrm{R} 2=0.005, \mathrm{~F}(9,1544)=0.845$ $p=0.575)$.

\section{Discussion}

Excess weight is an alarming problem worldwide not only among adults but also in the younger population which is more likely to become overweight or obese in adulthood, increasing the risk for the development of non-communicable diseases even in the period of adolescence [41]. The World Obesity Federation reported that in 2020 obesity reached a critical number of 158 million obese children, predicted to increase to 254 million by the year 2030. In 2016 , there were $11.5 \%$ and $6.5 \%$ boys and girls aged 5-9 with obesity in Latvia [6]. Our study showed a prevalence of $13.3 \%$ of obese children, $15.5 \%$ of boys, and $10.7 \%$ of girls, respectively (significantly higher in boys). These growing numbers indicate the need for determination of unhealthy lifestyle habits among children and the development of effective methods for prevention of obesity at such a young age.

\subsection{Unhealthy Eating Habits and Meal Portion Sizes}

Unhealthy EH and low PA levels are the major reasons for increasing obesity levels and are quite common among children all over the world. Skipping breakfast in childhood tends to become a persistent habit in adult life promoting overweight and obesity [42].In Latvia the number of 11-year-old children eating breakfast regularly has decreased in a decade from $76.3 \%$ t0 67.4\% in the year 2014 [18], while our study reported that only $59.2 \%$ pupils chose to have breakfast daily. In addition, the habit of having a regular breakfast tends to decrease in parallel with the increasing age of children [28]. In 2018, a study of children's anthropometric parameters and school environment reported that $3.2 \%$ of 9-year-old Latvian children skipped breakfast always [7], which is similar to our findings, while this is two-three times lower in comparison to children in Britain [43] and Italy [28]. Our study showed that in the OB group, skipping breakfast was more common than in NOR and UW groups, supporting the hypothesis that irregular breakfast leads to increased body weight. The rapid lifestyle of the modern world could be the main reason for unhealthy EHs such as skipping breakfast [44], thus it is of importance to highlight the need to find the time for a proper breakfast so it becomes a tradition.

It is recommended to consume three meals daily and one-three healthy snacks per day [45]. In addition, it is important to balance nutrient intake for proper growth and development. The current study is in line with studies performed in Lithuania [11] and Poland [29] and showed that almost 50\% of pupils have the recommended number of meals daily.

The WHO suggests consumption of more than $400 \mathrm{gr}$ of fruits and vegetables per day (five portions)as a part of a healthy diet low in fat, sugar and salt, reducing the risk of obesity [46]. According to the literature, vegetable daily consumption in 7-15-year-old children is critically low-approximately $25 \%-30 \%$ [7,18,47]. In Finland $43.3 \%$ of 11 -year-old children [21] and in Italy $48.8 \%$ of $8-9$-year-old children [28] avoid eating fruit and vegetables daily. In the current study, we analyzed the frequency of fruit and vegetable portions per day as the number of portions can unfold the real (more precise) fruit and vegetable EH. The results showed that only $7.3 \%$ of children do not eat vegetables at all, but more than one-third of pupils eat the recommended three or more portions of vegetables per day. Contrary, more than two-thirds of pupils eat the recommended two or more portions of fruits daily, while $2.8 \%$ of children do not eat fruits. Our study data also revealed that OB pupils less often reach the norm for both fruit and vegetable intake. In line with our data, children and adolescents in Canada who consumed fruit and vegetables five or more times per day did not belong to the overweight or obese group [48]. Low intake of vegetables and fruits has been associated with increased risk of obesity [49] and a small inverse association between BMI and eating fruit and vegetables has been reported [50]. However, our study data showed no such correlation, which is in line with the results of an Health Behaviour in School-Aged Children study in 2005 [47]. A recent systematic review reported that girls tend to have a higher or more frequent intake of vegetables and 
fruit than boys [22]. The current study showed that girls consume more portions of vegetables per day than boys, but there is no difference in fruit consumption. Consumption of fruits and vegetables is still inadequately low (especially in OB pupils) as less than half of the pupils reach five or more portions per day. This may be explained by such factors as inappropriate opinions about fruit/vegetable prices, low income and lack of knowledge [51].

Fresh fruits and vegetables are considered as the best snack [52] while low nutrient and energy dense snacks impair quality of nutrition and lead to weight gain [53]. In the current study, approximately half of the pupils reported fruits as the most common snack, but less than one quarter of children chose unhealthy snacks, while other studies report that sweet snacks every day are consumed by $27.8 \%$ of 11-15-year-old children [7] and 38.1\% of 7-9-year-old Latvian children [18]. It has been reported that boys eat more sweet snacks than girls [47]. Contrarily, the current study reported higher consumption of salty snacks in boys, and higher consumption of sweet baked good in girls. Furthermore, there was no association between snack choice and body measurements, except a weak correlation between WC and unhealthier snacks in OW group.

High consumption of sugar as sweetened beverages (SSBs) in young children is determined by (a) time spent watching TV; (b) parenting model; (c) school nutrition policies [54], and leads to weight gain and adverse health outcomes. Despite TV and online advertising, in the current study the most often chosen daily beverage, by $41 \%$ of children, was water, while one-third of children chose SSBs. In comparison, a study in similar age groups reported $6.5 \%$ of pupils using SSBs daily $[7,18]$. Daily SSBs consumption in different studies varies from $22 \%$ [29] to $40 \%$ [28] and more, and may provide an extra $350 \mathrm{kcal}$ for each $750 \mathrm{~mL}$ of SSBs [55].

Nowadays, eating culture has changed significantly. Time for family meals at the table often is replaced with TV, computer, and other devices, which is related to higher intake of SSBs, chips and decreased intake of fruits [56]. Indeed, the current study data showed that almost one-third of children used their mobile devices or watched TV during their meal. These children had significantly higher WC and BMI and in fact they ate significantly smaller portions of vegetables and more often chose calorie dense snacks, reflected also in the higher number of unhealthy EHs. There is strong evidence available reporting increased consumption of fast food, SSBs and decreased consumption of fruits and vegetables while watching TV [26] for more than two hours per day [28]. The current study shows that obesity prevalence is higher in boys than girls. As boys use mobile devices during the meal more often than girls, this could be one of the explanations for these sex differences. Other aspects could be that boys chose to have a larger portion of carbohydrate rich food on their plate daily and the average number of unhealthy EH in boys was higher.

Large meal portions increase daily energy intake and are considered one of the main factors causing obesity [57]. The current study data showed that boys in comparison to girls chose to put on the plate a bigger portion of carbohydrate and protein rich containing foods. Contrary to the findings of a recent study which showed that large meal portions favor excess weight gain in early childhood [58], there were no differences between the weight groups in this study.

\subsection{Physical Activity}

Along with a healthy diet, PA can have a fundamental role, not only in a child's growth period, but also in the prevention of non-communicable diseases throughout life [59]. However, a number of epidemiological studies have alerted concerns about low PA and high consumption of calorie dense foods in children [59]. Current data show that 8 out of 10 children enjoy being physically active, but pupils in the OB group preferred being less active compared to other weight groups $(p<0.05)$. Boys also reported having more additional PA outside the school, more training sessions per week, and were more active during breaks compared to girls, resulting in significantly higher time spent in MVPA and correspondingly increased total energy costs. However, only half of the pupils reached the WHO recommended 60 min of MVPA on weekdays during school time and additional training. If these structured PAs are the only ones throughout the week (with sedentary activities during weekends), 
then the number of children who reach the necessary amount of MVPA drops below 20\%. In addition, pupils in this study participate in the SFAC project which ensures five PE lessons per week instead of the two determined by the Ministry of Education and Science of Latvia. This could mean that most of the pupils in Latvia on average may have 1.5-2 h of MVPA less than average participants in SFAC. Interesting, The Childhood Health, Activity, and Motor Performance School Study Denmark reported no differences in overall PA levels between children attending sports schools and normal schools, as children who were more active during school time were less active during leisure time [60]. On the other hand, it has been suggested that PE is more effective in generating MVPA than other periods (e.g., exergaming, recess, and lunch break) [61] over the school day, in addition to after-school periods that can ensure around 30\% of daily MVPA [62]. Furthermore, significant differences between PA levels (total, light, moderate, or vigorous) among weight groups were not found in this study, while a study in Lithuania showed that overweight and obese children had lower PA and participated in MVPA $22.4 \mathrm{~min}$ less in comparison to the normal weight group [13].

Total energy costs for structured PA in different weight groups ranged from $1451 \mathrm{kcal} /$ week in UW children not reaching WHO recommendations, to 3081/week kcal in OB children reaching WHO recommendations. As total energy costs depend both on PA levels and weight determined BMR, there are significant differences between kcal used in the same weight group but with different MVPA levels, while we found no difference between the most distinct weight groups for different PA levels. For example, the total energy cost for UW pupils reaching WHO recommendations (2041 kcal/week) was similar to that of OB pupils not reaching the limit (2125 kcal/week). Children who used more kcal during PA also chose bigger portions of carbohydrate-containing foods and bigger portions of meat or fish, irrespectively of the weight group. At the same time, boys, besides significantly higher PA, also put more carbohydrate and protein rich foods on their plate and tended to eat more calorie dense snacks, which could add to previous explanations on obesity prevalence in girls and boys in this study. Similar results were found in the second wave of the population-based German Health Interview and Examination Survey for Children and Adolescents (2014-2017) [63]. On the other hand, current data shows the relation between increased PA and lower number of unhealthy EHs. These findings are in line with a previously mentioned study reporting higher PA level association with higher fruit/vegetable and lower soft drink consumption [63]. On the other hand, relations among any EH and PA in 7-10-year-old Italian children were not found [64]. Finally, the relation between enjoyment of PA and lower BMI and WC was found, pointing to the importance of facilitating pleasant PA in early childhood.

\subsection{Impact of $P A$ and $E H$ on $B M I$}

Despite the significant differences observed in various factors measured among different weight groups, the present study data failed to explain the variance in BMI, while only the number of vegetable and fruit portions per day was a significant predictor, of small effect size, for WC. Previously published data suggest that obesity is primarily determined by inherited genetic factors explaining $30 \%-70 \%$ variance in BMI $[65,66]$. Diet-related modifiable factors affecting childhood obesity include nutrient rich but low calorie foods, as well as eating habits described in this study [67]. A recent large-scale population study involving more than 250,000 children and adolescents suggested that current behaviors like television viewing and frequent nut consumption are more important predictors for BMI than early exposure to antibiotics, for example [68]. In addition, it has been shown that nutrition-related parenting practices were associated with BMI in children [69]. Finally, PA has been shown as a factor influencing BMI [70]. As reported previously, EH and PA have a comparatively small effect size on anthropometric measurements and thus a larger sample size as well as the inclusion of other factors (e.g., socio-economic status and parenting practices) could possibly have explained BMI and WC variance to a greater extent. 


\section{Limitations}

One of the possible limitations was that children could under- or over-report their actual $\mathrm{EH}$ and PA levels. However, in the current study we found objective differences within weight groups and sex. Another limitation could be that some pupils from the total sample size did not correctly understand the meaning of the question in the questionnaire due to inability to read it properly or maintain focus. To reduce this limitation, electronic questionnaires were designed to be as short as possible and illustrated with pictures. In addition, a researcher or a schoolteacher was available for any questions while children filled out the questionnaires. Slight deviations in the collection of anthropometric measurements by school nurses could be present, despite the provided instructions. This paper represents the baseline cross-sectional data of a longitudinal, prospective study, so any direction of association between the variables cannot yet be determined. Follow up data will be collected to confirm how the change in body mass index and waist circumference is related to dietary and physical activity variables.

\section{Conclusions}

A healthy lifestyle consists of a cluster of different habits and includes a proper diet and PA. $\mathrm{EH}$ and PA levels differ between sexes. Girls make healthier dietary choices (e.g., consume more fruits and vegetables, drink more water, and eat smaller portions of carbohydrate and protein rich foods), while boys spend more time in MVPA. In line with other studies, current data describe lower fruit and vegetable consumption among obese children. In addition, obese children skip breakfast more often. Furthermore, children who choose to have their meals in front of TV have higher BMI and WC, which in turn could be explained by a higher number of unhealthy EHs, for example, inadequately low consumption of vegetables and high consumption of calorie dense snacks. Additional structured PA in school (5 vs 2 PE lessons) and other training on weekdays cover weekly WHO recommendations for MVPA (420 min) in less than $20 \%$ of pupils. Association between factors (EH and time spent in PA) and BMI was not found in this study.

Author Contributions: Project design and supervision, D.R.; project administration, L.O.-M.; methodology, D.R., A.G.-G.; collection of data, D.R., I.J., J.R.; data analysis and representation, I.J.; collection of scientific literature, J.R., writing—original draft preparation, D.R., I.J., J.R.; writing—review and editing, D.R., A.G.-G., L.O.-M.; funding acquisition, D.R. All authors have read and agreed to the published version of the manuscript.

Funding: Effective collaboration project "The Physical Activity and Children overall Health Study (PACH study): Lifestyle as Human Gut Metagenome Modifiable Factor.", Nr. ZD2019/20861 between University of Latvia and Latvian Olympic Committee.

Acknowledgments: The authors are grateful to Latvian Olympic Committee, Ministry of Education and Science of Latvia and University of Latvia for the financial support. Thankful to all schools for participation in the project SFAC and this research, furthermore for the support during researcher visits.

Conflicts of Interest: The authors declare no conflict of interest.

\section{Appendix A}

Table A1. Estimation of nutrition and related behavior.

\begin{tabular}{cccc}
\hline Dietary Pattern & Survey Item & Answers & $\begin{array}{c}\text { Total number of } \\
\text { Unhealthy EH } \\
\text { (Criteria for Scoring) }\end{array}$ \\
\hline Main Meal Frequency & $\begin{array}{c}\text { How many main meals } \\
\text { do you have per day? } \\
{[11,21,29]}\end{array}$ & Recommendation: 3 meals [45] & \\
\hline
\end{tabular}


Table A1. Cont.

\begin{tabular}{|c|c|c|c|}
\hline Dietary Pattern & Survey Item & Answers & $\begin{array}{l}\text { Total number of } \\
\text { Unhealthy EH } \\
\text { (Criteria for Scoring) } \\
\end{array}$ \\
\hline Snacking Frequency & $\begin{array}{l}\text { How often do you eat } \\
\text { snack meals? }[28,30]\end{array}$ & $\begin{array}{l}\text { Recommendation: } 1-3 \text { snacks } \\
\text { [45] }\end{array}$ & \\
\hline Breakfast & $\begin{array}{c}\text { Do you eat breakfast? } \\
{[11,21,28,29]}\end{array}$ & $\begin{array}{ll}\text { 1. } & \text { Never } \\
\text { 2. } & \text { Sometimes } \\
\text { 3. } & \text { Almost every day } \\
\text { 4. } & \text { Every day }\end{array}$ & Point for answers 1 and 2. \\
\hline $\begin{array}{c}\text { Type of Preferred } \\
\text { Breakfast }\end{array}$ & $\begin{array}{c}\text { What do you usually } \\
\text { have for breakfast? } \\
\qquad[20,28]\end{array}$ & $\begin{array}{l}\text { Children were able to choose } \\
\text { one most common type of } \\
\text { meal from the given pictures. } \\
\text { 1. Porridge } \\
\text { 2. Sweet cereals } \\
\text { 3. Sandwich } \\
\text { 4. Milk products } \\
\text { 5. Eggs } \\
\text { 6. }\end{array}$ & \\
\hline Eating Culture & $\begin{array}{l}\text { How do you usually eat? } \\
\text { [31] }\end{array}$ & $\begin{array}{l}\text { Children were able to choose } \\
\text { usual eating behavior from the } \\
\text { given pictures. } \\
\text { 1. Eating dinner with } \\
\text { family at the table. } \\
\text { 2. Eating dinner alone } \\
\text { at table. } \\
\text { 3. Eating dinner in front } \\
\text { of TV. } \\
\text { 4. Eating dinner while or } \\
\text { scrolling the telephone. }\end{array}$ & Point for answers 3 and 4. \\
\hline $\begin{array}{c}\text { Portion Size of } \\
\text { Carbohydrate Rich Food }\end{array}$ & $\begin{array}{l}\text { How big a portion of } \\
\text { pasta, buckwheat, rice or } \\
\text { potatoes do you usually } \\
\text { have on your plate? [32] }\end{array}$ & $\begin{array}{l}\text { Children were able to choose } \\
\text { the most common portion size } \\
\text { of the meal from six given } \\
\text { pictures. }\end{array}$ & \\
\hline $\begin{array}{l}\text { Portion Size of } \\
\text { Vegetables/Salad }\end{array}$ & $\begin{array}{c}\text { How big a portion of } \\
\text { vegetables, salad do you } \\
\text { usually have on your } \\
\text { plate? [32] }\end{array}$ & \multirow{2}{*}{$\begin{array}{ll}\text { 1. } & \text { I don't eat } \\
\text { 2. } & 97 \mathrm{~g}^{*} ; 56 \mathrm{~g}^{* *} ; 56 \mathrm{~g}^{* * *} \\
\text { 3. } & 175 \mathrm{~g}^{*} ; 85 \mathrm{~g}^{* *} ; 108 \mathrm{~g} * * * \\
\text { 4. } & 253 \mathrm{~g}^{*} ; 145 \mathrm{~g}^{* *} ; 168 \mathrm{~g} * * * \\
\text { 5. } & 331 \mathrm{~g}^{* ;} ; 174 \mathrm{~g}^{* *} ; 191 \mathrm{~g}^{* * *} \\
\text { 6. } & 486 \mathrm{~g}^{*} ; 234 \mathrm{~g}^{* *} ; 308 \mathrm{~g}^{* * *}\end{array}$} & \\
\hline $\begin{array}{l}\text { Portion Size of Protein } \\
\text { Rich Food }\end{array}$ & $\begin{array}{l}\text { How big a portion of } \\
\text { meat or fish do you } \\
\text { usually have on your } \\
\text { plate? [32] }\end{array}$ & & \\
\hline Vegetables & $\begin{array}{c}\text { How many serves of } \\
\text { vegetables do you } \\
\text { usually eat per day? } \\
{[31,33]}\end{array}$ & $\begin{array}{l}\text { Inadequate consumption: } \\
\text { 1. I don't eat vegetables } \\
2 . \quad 1 \text { serve per day } \\
\text { 3. } 2 \text { serves per day } \\
\text { Adequate consumption: } \\
\text { 4. } \quad 3-4 \text { serves per day } \\
\text { 5. more than } 5 \text { serves } \\
\text { per day }\end{array}$ & Point for answers 1,2 , and 3. \\
\hline
\end{tabular}


Table A1. Cont.

\begin{tabular}{|c|c|c|c|}
\hline Dietary Pattern & Survey Item & Answers & $\begin{array}{l}\text { Total number of } \\
\text { Unhealthy EH } \\
\text { (Criteria for Scoring) }\end{array}$ \\
\hline Fruits & $\begin{array}{l}\text { How many serves of } \\
\text { fruits do you usually eat } \\
\text { per day? }[31,33]\end{array}$ & $\begin{array}{l}\text { Inadequate consumption: } \\
\text { 1. I don't eat fruits } \\
\text { 2. } 1 \text { serve per day } \\
\text { Adequate consumption: } \\
\text { 3. } 2 \text { serves per day } \\
\text { 4. } \quad \text { more than } 3 \text { serves } \\
\quad \text { per day }\end{array}$ & Point for answers 1 and 2 \\
\hline Type of preferred snacks & $\begin{array}{c}\text { What kind of snacks do } \\
\text { you usually eat? [34] }\end{array}$ & $\begin{array}{l}\text { Children were able to choose } \\
\text { the most common type of } \\
\text { snack from the given pictures. } \\
\text { Healthy snacks: } \\
\text { 1. Nuts, dried fruits } \\
\text { 2. Fresh fruits } \\
\text { 3. Yogurt } \\
\text { Unhealthy snacks: } \\
\text { 4. Cookies, sweet bakery } \\
\text { 5. Chips, salty nuts, French } \\
\text { fries, popcorn } \\
\text { 6. Chocolate, chocolate } \\
\text { sweets, ice-cream }\end{array}$ & Point for answers 4,5 , and 6 . \\
\hline $\begin{array}{c}\text { Type of preferred } \\
\text { beverage }\end{array}$ & $\begin{array}{c}\text { What kind of beverage } \\
\text { do you choose to drink } \\
\text { between meals? } \\
{[24,35,36]}\end{array}$ & $\begin{array}{l}\text { Children were able to choose } \\
\text { the most common beverage } \\
\text { from the given pictures. } \\
\text { 1. Water } \\
\text { 2. Tea } \\
\text { Sugar-sweetened beverages } \\
\text { (SSBs): } \\
\text { 3. Soft drinks (Coca-Cola, } \\
\text { Fanta, Sprite) } \\
\text { 4. Sweetened juices }\end{array}$ & Point for answers 3 and 4. \\
\hline
\end{tabular}

Portion Size of Carbohydrate Rich Food * Portion Size of Vegetables/Salad ${ }^{* *}$ Portion Size of Protein Rich Food ${ }^{* * *}$. 


\section{Appendix B}

Table A2. Estimation of structured physical activity levels on weekdays based on youth compendium of physical activity [39].

\begin{tabular}{|c|c|c|c|}
\hline Nr. & Survey Item & Description of Answers & Specific Activity/Code/METy Values \\
\hline 1 & $\begin{array}{l}\text { How much do you enjoy } \\
\text { active physical movement } \\
\text { e.g., jumping, running, } \\
\text { playing with the ball etc.? }\end{array}$ & $\begin{array}{l}\text { 1. I don't like to move } \\
\text { actively at all, I } \\
\text { rather sit still. } \\
\text { 2. I don't like to move } \\
\text { actively too much; I } \\
\text { rather walk slowly. } \\
\text { 3. On average I like to } \\
\text { move actively. } \\
\text { 4. I gladly } \\
\text { move actively. } \\
\text { 5. I use every chance to } \\
\text { move actively, } \\
\text { because I enjoy it } \\
\text { a lot. }\end{array}$ & \\
\hline 2 & How do you go to school? & $\begin{array}{ll}\text { 1. } & \text { Walking } \\
\text { 2. } & \text { With public transport } \\
\text { 3. } & \text { By car }\end{array}$ & \\
\hline 3 & $\begin{array}{l}\text { How long do you go to } \\
\text { school? }\end{array}$ & $\begin{array}{l}\text { 1. Less than } 10 \mathrm{~min} \\
\text { 2. } 10-30 \mathrm{~min} \\
\text { 3. Almost an hour }\end{array}$ & $\begin{array}{c}\text { Average: } 4.1 \\
\text { Walk Self-Paced Casual/803201/3.6 } \\
\text { Walk Self-Paced Brisk/803001/4.6 } \\
\text { Total energy cost (kcal) per } 20 \text { or } 45 \\
\text { min walk on average * } 5 \text { days. }\end{array}$ \\
\hline 4 & $\begin{array}{l}\text { How many sport lessons } \\
\text { do you have in school in a } \\
\text { week? } \\
\text { Ministry of Education and } \\
\text { Science of Latvia: } \\
\text { Minimum } 2 \text { physical } \\
\text { education lessons ( } 40 \mathrm{~min} \text { ) } \\
\text { per week. }\end{array}$ & $\begin{array}{ll}\text { 1. } & 2 \text { sport lessons } \\
\text { 2. } & 3 \text { sport lessons } \\
\text { 3. } & 4 \text { sport lessons } \\
\text { 4. } & 5 \text { sport lessons }\end{array}$ & $\begin{array}{c}\text { Warm up }(10 \mathrm{~min}) / \text { Average: } 4.7 \\
\text { Slow jogging/601201/5.5 } \\
\text { Strength } \\
\text { Exercises-Push-Ups/303001/3.9 } \\
\text { Jumping Jacks / 302401/4.6 } \\
\text { Games ( } 20 \text { min)/Average: } 5.9 \\
\text { Obstacle/Locomotor } \\
\text { Course-Moderate/103801/5.9 } \\
\text { Playing Games, e.g., Catch and Throw } \\
\text { Balls/10420X/5.9 } \\
\text { Cool down }(10 \text { min }) / 2.7 \\
\text { Gymnastics/302201/2.7 } \\
\text { Total energy cost (kcal) per sport } \\
\text { lesson * number of sport lessons per } \\
\text { week. }\end{array}$ \\
\hline 5 & $\begin{array}{l}\text { Do you attend other sports } \\
\text { (trainings) outside the } \\
\text { school, e.g., dancing, } \\
\text { basketball, athletics or any } \\
\text { other sports? }\end{array}$ & $\begin{array}{ll}\text { 1. } & \text { Yes } \\
\text { 2. } & \text { No }\end{array}$ & \\
\hline
\end{tabular}


Table A2. Cont.

\begin{tabular}{|c|c|c|c|}
\hline Nr. & Survey Item & Description of Answers & Specific Activity/Code/METy Values \\
\hline 6 & $\begin{array}{l}\text { What kind of sports do } \\
\text { you participate in? }\end{array}$ & Please write it down. & $\begin{array}{l}\text { METy adjusted to each individual } \\
\text { sport. } \\
\text { Sport trainings for 1st-3rd grade } \\
\text { pupils usually last 1:00-1:30 h. For } \\
\text { calculation of METy in pupils, average } \\
\text { time } 1: 15 \text { h }(75 \text { min) was taken. } \\
\text { Warm up (20 min)/Average: } 4.7 \\
\text { Slow jogging/601201/5.5 } \\
\text { Strength Exercises - } \\
\text { Push-Ups/303001/3.9 } \\
\text { Jumping Jacks/302401/4.6 } \\
\text { Active training }(40 \text { min)/depending on } \\
\text { the sports children are involved } \\
\text { Cool down }(15 \text { min }) / 2.7 \\
\text { Gymnastics/302201/2.7 }\end{array}$ \\
\hline
\end{tabular}

1. 0 times

2. 1 time

3. 2 times

4. 3 times

5. 4 and more times
Total energy cost $(\mathrm{kcal})$ for trainings $=$ Total energy cost $(\mathrm{kcal})$ in question 6 * number of trainings per week.
8

What did you mostly do during the breaks while you are in the school?
1. Video Games-Mobile Phone/352201/1.4

2. Average: 2.1

Standing/702001/1.7; Walk 0.5/801001, 2.5

1. Sat down (talking, reading, using my phone)

2. Stood or walked around

3. Run or played a little bit

4. Run around and played quite a lot

5. Run and played actively most of the time is approximately $50 \mathrm{~min}(3 * 10 \mathrm{~min}+$
3. Walk Self-Paced

Casual/803201/3.6

4. Playing

Tag-Moderate/104401/6.1

5. Playing

Tag-Vigorous/104601/7.4

Ministry of Education and Science of Latvia: from 1st-3rd grade pupils can have maximally 5 lessons per day.

Correspondingly total time for breaks lunch break (20-30 min)). Eating itself usually takes around $10 \mathrm{~min}$, thus for energy expenditure calculations during school breaks $40 \mathrm{~min}$ are used. Total energy cost $(\mathrm{kcal})=$ Total energy cost (kcal) for breaks between lessons * 5 days.

Time of moderate PA (3-6 METy) = (Average time to walk to school * 5 days $)+(30$ min of physical education lesson * number of lessons per week $)+(20$ min of trainings (warm up $) *$ number of trainings per week $)+(40$ min of active training if it is $<6 \mathrm{METy}{ }^{*}$ number of trainings per week) $+(40 \mathrm{~min}$ (breaks in the school, if answer 3 or 4 is marked) $* 5$ days $)$. Time of vigorous PA ( $>6 \mathrm{METy})=(40 \mathrm{~min}$ of active training if it is $>6 \mathrm{METy} *$ number of trainings per week $)+(40 \mathrm{~min}$ (breaks in the school, if answer 5 is marked $) * 5$ days).

\section{References}

1. WHO. Obesity and Overweight. Available online: https://www.who.int/news-room/fact-sheets/detail/ obesity-and-overweight (accessed on 28 August 2020).

2. Kolb, R.; Sutterwala, F.S.; Zhang, W. Obesity and cancer: Inflammation bridges the two. Curr. Opin. Pharmacol. 2016, 29, 77-89. [CrossRef] [PubMed] 
3. Fang, X.; Zuo, J.; Zhou, J.; Cai, J.; Chen, C.; Xiang, E.; Li, H.; Cheng, X.; Chen, P.; Li, S. Childhood obesity leads to adult type 2 diabetes and coronary artery diseases: A 2-sample mendelian randomization study. Medicine 2019, 98, e16825. [CrossRef] [PubMed]

4. Yoshida, Y.; Simoes, E.J. Sugar-Sweetened Beverage, Obesity, and Type 2 Diabetes in Children and Adolescents: Policies, Taxation, and Programs. Curr. Diab. Rep. 2018, 18, 31. [CrossRef] [PubMed]

5. Brown, C.L.; Halvorson, E.E.; Cohen, G.M.; Lazorick, S.; Skelton, J.A. Addressing Childhood Obesity. Opportunities for Prevention. Pediatr. Clin. North Am. 2015, 62, 1241-1261. [CrossRef]

6. World Obesity Federation. Atlas of Childhood Obesity. Available online: https://www.worldobesity.org/ nlsegmentation/global-atlas-on-childhood-obesity (accessed on 25 August 2020).

7. Disease Control and Prevention Center of Latvia. Study of Children's Anthropometric Parameters and School Environment. Available online: https://www.spkc.gov.lv/lv/veselibu-ietekmejoso-paradumu-petijumi (accessed on 28 August 2020).

8. Recasens, M.A.; Xicola-Coromina, E.; Manresa, J.M.; Ullmo, P.A.; Jensen, B.B.; Franco, R.; Suarez, A.; Nadal, A.; Vila, M.; Recasens, I.; et al. Impact of school-based nutrition and physical activity intervention on body mass index eight years after cessation of randomized controlled trial (AVall study). Clin. Nutr. 2019, 38, 2592-2598. [CrossRef] [PubMed]

9. Vieira-Ribeiro, S.A.; Andreoli, C.S.; Fonseca, P.C.A.; Miranda Hermsdorff, H.H.; Pereira, P.F.; Ribeiro, A.Q.; Priore, S.E.; Franceschini, S.C.C. Dietary patterns and body adiposity in children in Brazil: A cross-sectional study. Public Health 2019, 166, 140-147. [CrossRef]

10. Herbenick, S.K.; James, K.; Milton, J.; Cannon, D. Effects of family nutrition and physical activity screening for obesity risk in school-age children. J. Spec. Pediatr. Nurs. 2018, 23. [CrossRef]

11. Smetanina, N.; Albaviciute, E.; Babinska, V.; Karinauskiene, L.; Albertsson-Wikland, K.; Petrauskiene, A.; Verkauskiene, R. Prevalence of overweight/obesity in relation to dietary habits and lifestyle among 7-17 years old children and adolescents in Lithuania Health behavior, health promotion and society. BMC Public Health 2015, 15, 1001. [CrossRef]

12. Rocha, N.P.; Milagres, L.C.; Filgueiras, M.D.S.; Suhett, L.G.; Silva, M.A.; de Albuquerque, F.M.; Ribeiro, A.Q.; Vieira, S.A.; de Novaes, J.F. Association of Dietary Patterns with Excess Weight and Body Adiposity in Brazilian Children: The Pase-Brasil Study. Arq. Bras. Cardiol. 2019, 113, 52-59. [CrossRef]

13. Raistenskis, J.; Sidlauskiene, A.; Strukcinskiene, B.; Ugur Baysal, S.; Buckus, R. Physical activity and physical fitness in obese, overweight, and normal-weight children. TURKISH J. Med. Sci. 2016, 46, 443-450. [CrossRef]

14. Fairclough, S.J.; Dumuid, D.; Taylor, S.; Curry, W.; McGrane, B.; Stratton, G.; Maher, C.; Olds, T. Fitness, fatness and the reallocation of time between children's daily movement behaviours: An analysis of compositional data. Int. J. Behav. Nutr. Phys. Act. 2017, 14, 1-12. [CrossRef] [PubMed]

15. Eurostat-Data Explorer. Body mass index (BMI) by sex, age and educational attainment level. Available online: https://appsso.eurostat.ec.europa.eu/nui/show.do?dataset=hlth_ehis_bm1e\&lang= en (accessed on 28 August 2020).

16. Benjamin, E.J.; Blaha, M.J.; Chiuve, S.E.; Cushman, M.; Das, S.R.; Deo, R.; De Ferranti, S.D.; Floyd, J.; Fornage, M.; Gillespie, C.; et al. Heart Disease and Stroke Statistics'2017 Update: A Report from the American Heart Association. Circulation 2017, 135, e146-e603. [CrossRef] [PubMed]

17. Keaver, L.; Webber, L.; Dee, A.; Shiely, F.; Marsh, T.; Balanda, K.; Perry, I. Application of the UK foresight obesity model in Ireland: The health and economic consequences of projected obesity trends in Ireland. PLoS ONE 2013, 8, e79827. [CrossRef]

18. Pudule, I.; Velika, B.; Grīnberga, D.; Gobina, I.; Villeruša, A. Health Behaviour in School-aged Children; HBSC: Riga, Latvia, 2015; p. 52.

19. WHO. BMI-for-age (5-19 years). Available online: https://www.who.int/growthref/who2007_bmi_for_age/en/ (accessed on 28 August 2020).

20. Giménez-Legarre, N.; Flores-Barrantes, P.; Miguel-Berges, M.L.; Moreno, L.A.; Santaliestra-Pasías, A.M. Breakfast Characteristics and Their Association with Energy, Macronutrients, and Food Intake in Children and Adolescents: A Systematic Review and Meta-Analysis. Nutrients 2020, 12, 2460. [CrossRef] [PubMed]

21. de Oliveira Figueiredo, R.A.; Viljakainen, J.; Viljakainen, H.; Roos, E.; Rounge, T.B.; Weiderpass, E. Identifying eating habits in Finnish children: A cross-sectional study. BMC Public Health 2019, 19, 312. [CrossRef] [PubMed] 
22. Rasmussen, M.; Krølner, R.; Klepp, K.I.; Lytle, L.; Brug, J.; Bere, E.; Due, P. Determinants of fruit and vegetable consumption among children and adolescents: A review of the literature. Part I: Quantitative studies. Int. J. Behav. Nutr. Phys. Act. 2006, 3, 22. [CrossRef]

23. Potter, M.; Vlassopoulos, A.; Lehmann, U. Snacking Recommendations Worldwide: A Scoping Review. Adv. Nutr. 2018, 9, 86-98. [CrossRef]

24. Vieux, F.; Maillot, M.; Constant, F.; Drewnowski, A. Water and beverage consumption patterns among 4 to 13-year-old children in the United Kingdom. BMC Public Health 2017, 17, 479. [CrossRef]

25. Hebestreit, A.; Intemann, T.; Siani, A.; De Henauw, S.; Eiben, G.; Kourides, Y.; Kovacs, E.; Moreno, L.; Veidebaum, T.; Krogh, V.; et al. Dietary Patterns of European Children and Their Parents in Association with Family Food Environment: Results from the I.Family Study. Nutrients 2017, 9, 126. [CrossRef]

26. Avery, A.; Anderson, C.; McCullough, F. Associations between children's diet quality and watching television during meal or snack consumption: A systematic review. Matern. Child Nutr. 2017, 13, e12428. [CrossRef]

27. Robinson, T.N.; Banda, J.A.; Hale, L.; Lu, A.S.; Fleming-Milici, F.; Calvert, S.L.; Wartella, E. Screen Media Exposure and Obesity in Children and Adolescents. Pediatrics 2017, 140, S97-S101. [CrossRef] [PubMed]

28. Lauria, L.; Spinelli, A.; Cairella, G.; Censi, L.; Nardone, P.; Buoncristiano, M. Dietary habits among children aged 8-9 years in Italy. Ann. Ist. Super. Sanita 2015, 51, 371-381. [CrossRef] [PubMed]

29. Szczepańska, E.; Szeja, N.; Szymkiewicz, A.; Kowalska, A.; Lenard, B.; Bulwicka, A. Eating behaviours of middle- and secondary-school pupils from the upper Silesian region in Poland. Rocz. Państwowego Zakładu Hig. 2014, 65, 337-344.

30. Story, M.; Holt, K.; Sofka, D. Bright Futures in Practice: Nutrition, 2nd ed.; National Center for Education in Maternal and Child Health and Georgetown University: Arlington, VA, USA, 2002.

31. Wilson, A.M.; Magarey, A.M.; Mastersson, N. Reliability and relative validity of a child nutrition questionnaire to simultaneously assess dietary patterns associated with positive energy balance and food behaviours, attitudes, knowledge and environments associated with healthy eating. Int. J. Behav. Nutr. Phys. Act. 2008, 5, 5. [CrossRef] [PubMed]

32. Ali, H.I.; Platat, C.; El Mesmoudi, N.; El Sadig, M.; Tewfik, I. Evaluation of a photographic food atlas as a tool for quantifying food portion size in the United Arab Emirates. PLoS ONE 2018, 13, e0196389. [CrossRef]

33. Pearson, N.; Timperio, A.; Salmon, J.; Crawford, D.; Biddle, S.J. Family influences on children's physical activity and fruit and vegetable consumption. Int. J. Behav. Nutr. Phys. Act. 2009, 6, 34. [CrossRef]

34. Julian, C.; Santaliestra-Pasías, A.M.; Miguel-Berges, M.L.; Moreno, L.A. Frequency and quality of mid-afternoon snack among Spanish children. Nutr. Hosp. 2017, 34, 827-833. [CrossRef]

35. Sui, Z.; Zheng, M.; Zhang, M.; Rangan, A. Water and Beverage Consumption: Analysis of the Australian 2011-2012 National Nutrition and Physical Activity Survey. Nutrients 2016, 8, 678. [CrossRef]

36. Bleich, S.N.; Vercammen, K.A.; Koma, J.W.; Li, Z. Trends in Beverage Consumption Among Children and Adults, 2003-2014. Obesity 2018, 26, 432-441. [CrossRef]

37. Abu Dhabi Food Control Authority. A Photographic Atlas of Food Portions for the Emirate of Abu Dhabi. Available online: https:/docplayer.net/45546937-A-photographic-atlas-of-food-portions-for-the-emirate-ofabu-dhabi.html (accessed on 25 August 2020).

38. Chen, W.; Hammond-Bennett, A.; Hypnar, A.; Mason, S. Health-related physical fitness and physical activity in elementary school students. BMC Public Health 2018, 18, 195. [CrossRef] [PubMed]

39. Butte, N.F.; Watson, K.B.; Ridley, K.; ZakeriI, I.F.; Mcmurray, R.G.; Pfeiffer, K.A.; Crouter, S.E.; Herrmann, S.D.; Basset, D.R.; Long, A.; et al. A Youth Compendium of Physical Activities. Med. Sci. Sport. Exerc. 2018, 50, 246-256. [CrossRef] [PubMed]

40. World Health Organization. Childhood Obesity Surveillance Initi ati ve (COSI) Protocol; World Health Organization: Geneva, Switzerland, 2017.

41. Bhadoria, A.; Sahoo, K.; Sahoo, B.; Choudhury, A.; Sufi, N.; Kumar, R. Childhood obesity: Causes and consequences. J. Fam. Med. Prim. Care 2015, 4, 187. [CrossRef] [PubMed]

42. Szajewska, H.; Ruszczyński, M. Systematic review demonstrating that breakfast consumption influences body weight outcomes in children and adolescents in Europe. Crit. Rev. Food Sci. Nutr. 2010, 50, 113-119. [CrossRef] [PubMed]

43. Coulthard, J.D.; Palla, L.; Pot, G.K. Breakfast consumption and nutrient intakes in 4-18-year-olds: UK National Diet and Nutrition Survey Rolling Programme (2008-2012). Br. J. Nutr. 2017, 118, 280-290. [CrossRef] 
44. Scaglioni, S.; De Cosmi, V.; Ciappolino, V.; Parazzini, F.; Brambilla, P.; Agostoni, C. Factors Influencing Children's Eating Behaviours. Nutrients 2018, 10, 706. [CrossRef]

45. Ministry of Health of Republic of Latvia Dietary giudelines for children aged 2-18. Available online: https://www.vm.gov.lv/images/userfiles/uztura_ieteikumi_berniem_2_lidz_18_gadi.pdf (accessed on 28 August 2020).

46. Hartley, L.; Igbinedion, E.; Holmes, J.; Flowers, N.; Thorogood, M.; Clarke, A.; Stranges, S.; Hooper, L.; Rees, K. Increased consumption of fruit and vegetables for the primary prevention of cardiovascular diseases. Cochrane Database Syst. Rev. 2013, 2013. [CrossRef]

47. Janssen, I.; Katzmarzyk, P.T.; Boyce, W.F.; Vereecken, C.; Mulvihill, C.; Roberts, C.; Currie, C.; Pickett, W.; Ńemeth, Á.; Ojala, K.; et al. Comparison of overweight and obesity prevalence in school-aged youth from 34 countries and their relationships with physical activity and dietary patterns. Obes. Rev. 2005, 6, 123-132. [CrossRef]

48. Colapinto, C.K.; Graham, J.; St-Pierre, S. Trends and correlates of frequency of fruit and vegetable consumption, 2007 to 2014. Health Rep. 2018, 29, 9-14.

49. Ledoux, T.A.; Hingle, M.D.; Baranowski, T. Relationship of fruit and vegetable intake with adiposity: A systematic review. Obes. Rev. 2011, 12, e143-e150. [CrossRef]

50. Wall, C.R.; Stewart, A.W.; Hancox, R.J.; Murphy, R.; Braithwaite, I.; Beasley, R.; Mitchell, E.A.; Gómez, M.; Weyler, J.; Pinto-Vargas, R.; et al. Association between Frequency of Consumption of Fruit, Vegetables, Nuts and Pulses and BMI: Analyses of the International Study of Asthma and Allergies in Childhood (ISAAC). Nutrients 2018, 10, 316. [CrossRef] [PubMed]

51. Gerritsen, S.; Harré, S.; Swinburn, B.; Rees, D.; Renker-Darby, A.; Bartos, A.E.; Waterlander, W.E. Systemic Barriers and Equitable Interventions to Improve Vegetable and Fruit Intake in Children: Interviews with National Food System Actors. Int. J. Environ. Res. Public Health 2019, 16, 1387. [CrossRef] [PubMed]

52. American Academy of Pediatrics. Choosing Healthy Snacks for Kids-HealthyChildren.org. Available online: https://www.healthychildren.org/English/healthy-living/nutrition/Pages/ChoosingHealthy-Snacks-for-Children.aspx (accessed on 25 August 2020).

53. Shriver, L.H.; Marriage, B.J.; Bloch, T.D.; Spees, C.K.; Ramsay, S.A.; Watowicz, R.P.; Taylor, C.A. Contribution of snacks to dietary intakes of young children in the United States. Matern. Child Nutr. 2018, 14. [CrossRef] [PubMed]

54. Mazarello Paes, V.; Hesketh, K.; O’Malley, C.; Moore, H.; Summerbell, C.; Griffin, S.; van Sluijs, E.M.F.; Ong, K.K.; Lakshman, R. Determinants of sugar-sweetened beverage consumption in young children: A systematic review. Obes. Rev. 2015, 16, 903-913. [CrossRef]

55. Keller, A.; Bucher Della Torre, S. Sugar-Sweetened Beverages and Obesity among Children and Adolescents: A Review of Systematic Literature Reviews. Child. Obes. 2015, 11, 338-346. [CrossRef]

56. Trofholz, A.C.; Tate, A.; Loth, K.; Neumark-Sztainer, D.; Berge, J.M. Watching Television while Eating: Associations with Dietary Intake and Weight Status among a Diverse Sample of Young Children. J. Acad. Nutr. Diet. 2019, 119, 1462-1469. [CrossRef]

57. Kling, S.M.R.; Roe, L.S.; Keller, K.L.; Rolls, B.J. Double trouble: Portion size and energy density combine to increase preschool children's lunch intake. Physiol. Behav. 2016, 162. [CrossRef]

58. Syrad, H.; Llewellyn, C.H.; Johnson, L.; Boniface, D.; Jebb, S.A.; van Jaarsveld, C.H.M.; Wardle, J. Meal size is a critical driver of weight gain in early childhood. Sci. Rep. 2016, 6. [CrossRef]

59. Hebestreit, A.; Bogl, L.H. Dietary Behavior and Physical Activity in Children and Adolescents. Nutrients 2019, 11, 1849. [CrossRef]

60. Møller, N.C.; Tarp, J.; Kamelarczyk, E.F.; Brønd, J.C.; Klakk, H.; Wedderkopp, N. Do extra compulsory physical education lessons mean more physically active children-Findings from the childhood health, activity, and motor performance school study Denmark (The CHAMPS-study DK). Int. J. Behav. Nutr. Phys. Act. 2014, 11, 121. [CrossRef]

61. Gao, Z.; Chen, S.; Huang, C.C.; Stodden, D.F.; Xiang, P. Investigating elementary school children's daily physical activity and sedentary behaviours during weekdays. J. Sports Sci. 2017, 35, 99-104. [CrossRef] [PubMed] 
62. Arundell, L.; Hinkley, T.; Veitch, J.; Salmon, J. Contribution of the After-School Period to Children's Daily Participation in Physical Activity and Sedentary Behaviours. PLoS ONE 2015, 10, e0140132. [CrossRef] [PubMed]

63. Manz, K.; Mensink, G.B.M.; Finger, J.D.; Haftenberger, M.; Brettschneider, A.K.; Barbosa, C.L.; Krug, S.; Schienkiewitz, A. Associations between physical activity and food intake among children and adolescents: Results of KIGGS wave 2. Nutrients 2019, 11, 1060. [CrossRef] [PubMed]

64. Giontella, A.; Bonafini, S.; Tagetti, A.; Bresadola, I.; Minuz, P.; Gaudino, R.; Cavarzere, P.; Ramaroli, D.A.; Marcon, D.; Branz, L.; et al. Relation between dietary habits, physical activity, and anthropometric and vascular parameters in children attending the primary school in the Verona South District. Nutrients 2019, 11, 1070. [CrossRef] [PubMed]

65. Chesi, A.; Grant, S.F.A. The Genetics of Pediatric Obesity. Trends Endocrinol. Metab. 2015, 26, 711-721. [CrossRef] [PubMed]

66. Llewellyn, C.H.; Trzaskowski, M.; Plomin, R.; Wardle, J. Finding the missing heritability in pediatric obesity: The contribution of genome-wide complex trait analysis. Int. J. Obes. 2013, 37, 1506-1509. [CrossRef] [PubMed]

67. Kim, J.; Lim, H. Nutritional Management in Childhood Obesity. J. Obes. Metab. Syndr. 2019, 28, 225-235. [CrossRef]

68. Mitchell, E.A.; Stewart, A.W.; Braithwaite, I.; Murphy, R.; Hancox, R.J.; Wall, C.; Beasley, R. Factors associated with body mass index in children and adolescents: An international cross-sectional study. PLoS ONE 2018, 13, e0196221. [CrossRef]

69. Vaitkevičiūtè, J.; Petrauskienè, A. The Associations between Body Mass Index of Seven- and Eight-Year-Old Children, Dietary Behaviour and Nutrition-Related Parenting Practices. Medicina 2019, 55, 24. [CrossRef]

70. Hong, I.; Coker-Bolt, P.; Anderson, K.R.; Lee, D.; Velozo, C.A. Relationship Between Physical Activity and Overweight and Obesity in Children: Findings From the 2012 National Health and Nutrition Examination Survey National Youth Fitness Survey. Am. J. Occup. Ther. 2016, 70, 1-8. [CrossRef]

Publisher's Note: MDPI stays neutral with regard to jurisdictional claims in published maps and institutional affiliations.

(C) 2020 by the authors. Licensee MDPI, Basel, Switzerland. This article is an open access article distributed under the terms and conditions of the Creative Commons Attribution (CC BY) license (http://creativecommons.org/licenses/by/4.0/). 